\title{
Empirical Research on the Relationship between R\&D Investment and Financial Performance of Small and Medium-sized Enterprises
}

\author{
Tingfa Zhang \\ Research Department, Qilu Normal University, China \\ ztfsdu2011@163.com
}

\begin{abstract}
Keywords: R\&D Investment; Financial Performance; R\&D; Small and Medium-sized Enterprises
\end{abstract}
\begin{abstract}
With the development of China's market economy in depth, enterprises have become the main investment in research and development, so that the significance of R\&D activities and their management is more significant. This paper is based on the high-tech achievements of the information technology industry, focusing on the survival and development of small and medium enterprises, R\&D investment for small and medium enterprises, the importance of R\&D investment and corporate financial performance and whether there is a close relationship. Through the statistical investigation and analysis of R\&D investment in China's small and medium-sized listed companies, this paper reveals the correlation between $R \& D$ investment and enterprise efficiency and the contribution to the development of enterprises, so that enterprises have a correct understanding of $\mathrm{R} \& \mathrm{D}$ investment performance.
\end{abstract}

\section{Introduction}

R\&D activities are the source of the core competitiveness of enterprises, which plays a very crucial role to enhance the competitiveness of enterprises and promote sustained and rapid development of enterprises. In recent years, China's enterprises are gradually aware of that $R \& D$ activities is the key to improve the core competitiveness of enterprises, so R\&D investment in scientific and technological innovation will meet consumer differentiation and diversified consumer demand and can reduce costs and lead to excess profits.

Although small and medium-sized enterprise technology innovation of our country has many problems, such as the limited financing channels, capital bottleneck of the foundation is weak, the scientific research strength, but in order to survive, develop and expand, small and medium-sized enterprises have to research and development activities.

\section{Small and Medium-Sized Enterprise Status}

China's current standards for the division of small and medium-sized enterprises is to implement the "People's Republic of China SME Promotion Law" in 2003, the State Economic and Trade Commission, the State Development Planning Commission, the Ministry of Finance and the National Bureau of Statistics jointly issued the "Interim Provisions on SME standards" , Small and medium-sized enterprises that stipulate that the industrial sector must meet the following conditions: the number of employees is less than 2,000, or the sales amount is less than 300 million yuan, or the total assets are less than 400 million yuan.

In May 17, 2004, the China Securities Regulatory Commission officially announced the Shenzhen Stock Exchange SME board was allowed to set up. June 25, 2004, the first batch of eight small board companies listed, until now, there are 584 companies listed here. Small and medium-sized board of the main industry prominent, with the growth and technological content of small and medium enterprises to provide direct financing platform, adhering to the "market first, service-oriented" concept for SMEs to provide "high quality, convenient, fast and efficient" The development of small and medium enterprises, and then contribute to the national economic development. 
Table1 The number of listed companies in the SME sector at the end of each year

\begin{tabular}{|l|l|l|l|l|l|l|l|l|}
\hline year & 2004 & 2005 & 2006 & 2007 & 2008 & 2009 & 2010 & 2011 \\
\hline number & 38 & 50 & 102 & 202 & 273 & 327 & 531 & 584 \\
\hline
\end{tabular}

\section{R\&D Investment and Financial Performance}

R\&D Funding Investment. Enterprises in the fierce competition in the market to survive and develop as well as access to excess profits, we must have the core technology, to seize the high ground, we must through research and development to achieve these advantages, the use of new science, new principles, new technologies, new technology Basic research, applied research, development research and a series of activities. $R \& D$ investment in an enterprise usually refers to the material and manpower invested in these R\&D-related activities.

Research and development investment includes two aspects :R\&D funding investment and R\&D manpower investment. Developed countries experience indicate that $R \& D$ strength (R\&D expenditure accounted for the proportion of sales revenue) only reach more than $5 \%$ of sales income to have a strong competitive capacity, $2 \%$ of sales income can maintain the basic survival of enterprises, $1 \%$ of enterprises is extremely difficult to survive. Moreover, as the market demand for the core competitiveness of the higher enterprises, R\&D intensity will also show an upward trend. On the other hand, human resources as an important source of scientific and technological progress, has been more and more countries attention. Any science and technology are created by the people, the invention of science and technology and its applications are inseparable from the corresponding human resources, human resources investment is a prerequisite for scientific and technological progress. Research and development ability is an important ability of human resources to show in the process of technological invention and scientific and technological progress.

Financial Performance. Financial performance is an enterprise benefit that is presented in the financial statements (mainly financial statements) using the data on the financial position and results of the operations. Business profitability, development capacity, solvency and other aspects of capacity and performance, to a certain extent, can be used to reflect the financial statements data. Although some of the information that can not be reflected in the statements is of considerable importance to the description of firm performance, but this information is difficult to estimate, difficult to numerical, not suitable for empirical research, so this paper selected financial indicators as a corporate performance assessment To study the impact of R \& D investment on financial performance that represents firm performance and to explore the correlation between the two.

\section{Analysis of R\&D Investment and R\&D Intensity}

Descriptive Statistical Analysis of R\&D Investment. In this paper, 19 listed companies with continuous disclosure of $R \& D$ investment in 2008-2010 were selected as research samples. The statistical analysis of the absolute amount of R\&D investment, the results are as follows.

Table2 R\&D investment absolute number statistical description

\begin{tabular}{|l|l|l|l|}
\hline R\&D & 2008 & 2009 & 2010 \\
\hline mean & 3674.43 & 5179.25 & 5811.95 \\
\hline median & 2797.56 & 4680.09 & 5058.1 \\
\hline maximum & 8886.51 & 13304.58 & 16746.59 \\
\hline minimum & 765.52 & 718.08 & 1272.71 \\
\hline sample variance & $5.36 \mathrm{E}+06$ & $1.10 \mathrm{E}+07$ & $1.41 \mathrm{E}+07$ \\
\hline total & 69814.12 & 98405.78 & 110427.07 \\
\hline Sample number & 19 & 19 & 19 \\
\hline
\end{tabular}


We can see from the table, whether the R\&D investment amount of the average, median, maximum, or the sum is growing. Reflecting the company's emphasis on R\&D and innovation in the upgrade, but the maximum and minimum difference between the larger, indicating that the company's R\&D investment and the degree of attention is different. In 2008, R\&D investment in the main business income is 9.72 times the minimum input business, while the $R \& D$ investment is a difference of 10.61 times the $2010 \mathrm{R} \& \mathrm{D}$ investment in the main business income is the least input business 7.82 times, and R\&D investment difference 12.16 times.

Descriptive Statistical Analysis of R\&D Intensity.

Sample Distribution of R\&D intensity in Sample Enterprises is shown in the table 3.

Table3 Sample Distribution of R\&D intensity in Sample Enterprises

\begin{tabular}{|l|l|l|l|}
\hline \multicolumn{1}{|c|}{ Interval distribution(\%) } & $\begin{array}{l}\text { samples } \\
\text { number in 2008 }\end{array}$ & $\begin{array}{l}\text { samples number } \\
\text { in 2009 }\end{array}$ & $\begin{array}{l}\text { samples number } \\
\text { in 2010 }\end{array}$ \\
\hline $0-5$ & 3 & 2 & 3 \\
\hline $5-7$ & 5 & 3 & 4 \\
\hline $7-15$ & 9 & 10 & 9 \\
\hline $15-20$ & 2 & 3 & 2 \\
\hline More than 20 & 0 & 1 & 1 \\
\hline total & 19 & 19 & 19 \\
\hline
\end{tabular}

R\&D strength from the input value can be seen, the sample $R \& D$ investment intensity is relatively stable, the intensity of $7 \%-15 \%$ between the business accounted for about half of the more than $7 \%$ of the enterprises accounted for more than half of the total number of samples. R\&D investment also showed a slow upward trend, indicating that the overall business on the importance of R\&D have more understanding. And the past two years there have been R \& D strength of more than $20 \%$ of the enterprises, indicating that China's SMEs pay more and more attention to R\&D innovation, and the company funds to allow the range of R\&D investment, from 2009 data and 2008 comparison Performance significantly. Combined with statistical data and theoretical analysis, it can be inferred that the overall trend of R\&D investment is rising steadily.

\section{Empirical Study on R\&D Investment and Financial Performance}

The absolute amount of $R \& D$ investment used in the study is derived from the annual report. Financial performance indicators of the main business income, net profit yield from Guotai An database directly downloaded.

Empirical Study on the Correlation between R\&D Investment and Main Business Revenue. This paper studies the R\&D investment as independent variable, the main business income, net assets yield as the dependent variable, the establishment of $R \& D$ investment and financial performance of the linear regression model.

$$
y_{i}=\alpha+\beta x_{i}+\varepsilon_{i} .
$$

Where, $y_{i}$ is dependent variable which stands for financial performance, $x_{i}$ is explanatory variables which stands for R\&D investment, $\varepsilon_{i}$ is random error term.

As the impact of R\&D investment on financial performance is lagging behind, we should also examine the impact of R\&D investment in 2008 on financial performance in 2009 and 2010 respectively. Similarly, we should also examine the impact of R\&D investment in 2009 on financial performance in 2010.

The regression results are shown in the table 4. 
Table 4 Analysis on the Correlation between R\&D Investment and Main Business Revenue in 2008-2010

\begin{tabular}{|c|c|c|c|c|}
\hline & R\&D investment 2010 & R\&D investment 2009 & R\&D investment 2008 \\
\hline \multirow{3}{*}{$\begin{array}{l}\text { main } \\
\text { business } \\
\text { revenue } \\
2010\end{array}$} & $\begin{array}{l}\mathrm{x} \text { item } \\
\text { coefficient }\end{array}$ & $\begin{array}{l}\text { positive(significa } \\
\text { ntly) }\end{array}$ & $\begin{array}{l}\text { positive(significa } \\
\text { ntly) }\end{array}$ & $\begin{array}{l}\text { positive(significa } \\
\text { ntly) }\end{array}$ \\
\hline & $\mathrm{t}$ & 5.400 & 5.138 & 4.200 \\
\hline & $\mathrm{F}$ & 29.114 & 26.400 & 17.636 \\
\hline \multirow{3}{*}{$\begin{array}{l}\text { main } \\
\text { business } \\
\text { revenue } \\
2009\end{array}$} & $\begin{array}{l}\mathrm{x} \text { item } \\
\text { coefficient }\end{array}$ & & $\begin{array}{l}\text { positive(significa } \\
\text { ntly) }\end{array}$ & $\begin{array}{l}\text { positive(significa } \\
\text { ntly) }\end{array}$ \\
\hline & $\mathrm{t}$ & & 6.030 & 5.160 \\
\hline & $\mathrm{F}$ & & 36.420 & 26.622 \\
\hline \multirow{3}{*}{$\begin{array}{l}\text { main } \\
\text { business } \\
\text { revenue } \\
2008\end{array}$} & $\begin{array}{l}\mathrm{x} \text { item } \\
\text { coefficient }\end{array}$ & & & $\begin{array}{l}\text { positive(significa } \\
\text { ntly) }\end{array}$ \\
\hline & $\mathrm{t}$ & & & 5.310 \\
\hline & $\mathrm{F}$ & & & 28.189 \\
\hline
\end{tabular}

From Table 4, it can be found that there is a correlation between the main business income and the absolute number of R\&D investment. At the same time, the R\&D investment in 2008 and 2008, 2009, 2010, the main business income there is a positive correlation, and through the 0.01 significant hypothesis test, very statistically significant. Similar data are available for 2009 and 2010. Which proves that there is a positive correlation between R\&D investment and performance indicators of main business income. However, the significant correlation between the R\&D investment and the income from the main business income in the past year is reduced year by year. This shows that the $\mathrm{R}$ \&D investment will have an effect in the year, but still affect the future year.

Analysis of the Correlation between R\&D Investment and ROE. . The regression results are shown in the table 5.

Table 5 Analysis on the Correlation between R\&D Investment and Main Business Revenue in 2008-2010

\begin{tabular}{|c|c|c|c|c|}
\hline & & $\begin{array}{l}\text { R\&D investment } \\
2010\end{array}$ & R\&D investment 2009 & R\&D investment 2008 \\
\hline \multirow[t]{3}{*}{$\begin{array}{l}\text { ROE } \\
2010\end{array}$} & $\begin{array}{l}\mathrm{x} \text { item } \\
\text { coefficient }\end{array}$ & $\begin{array}{l}\text { positive(not } \\
\text { significant) }\end{array}$ & $\begin{array}{l}\text { positive(not } \\
\text { significant) }\end{array}$ & $\begin{array}{l}\text { positive(not } \\
\text { significant) }\end{array}$ \\
\hline & $\mathrm{t}$ & 1.599 & 1.239 & 0.631 \\
\hline & $\mathrm{F}$ & 2.557 & 1.536 & 0.398 \\
\hline \multirow[t]{3}{*}{$\begin{array}{l}\text { ROE } \\
2009\end{array}$} & $\begin{array}{l}\mathrm{x} \text { item } \\
\text { coefficient }\end{array}$ & & $\begin{array}{l}\text { positive(significa } \\
\text { ntly) }\end{array}$ & $\begin{array}{l}\text { positive(significa } \\
\text { ntly) }\end{array}$ \\
\hline & $\mathrm{t}$ & & 3.664 & 2.693 \\
\hline & $\mathrm{F}$ & & 13.426 & 7.253 \\
\hline \multirow[t]{3}{*}{$\begin{array}{l}\text { ROE } \\
2008\end{array}$} & $\begin{array}{l}\mathrm{x} \text { item } \\
\text { coefficient }\end{array}$ & & & $\begin{array}{l}\text { positive(significa } \\
\text { ntly) }\end{array}$ \\
\hline & $\mathrm{t}$ & & & 1.993 \\
\hline & $\mathrm{F}$ & & & 3.971 \\
\hline
\end{tabular}

As can be seen from Table 4, there is no significant correlation between the return on net assets and the absolute number of R\&D investment. R\&D investment in 2008 and 2008, 2010, the return on net assets are not significant, and 2009 net assets yield is positively correlated with the significance level of 0.05 significant test. Only the R\&D investment in 2009 and the return on net assets in 2009 passed a significant hypothesis test with a significant level of 0.01 , and the correlation with 2010 was not 
significant. $2010 \mathrm{R} \& \mathrm{D}$ investment and the 2010 return on net assets of the correlation is not significant

\section{References}

[1] Chen CJ, Huang YF, Lin BW. How firms innovate through R\&D internationalization? An S-curve hypothesis [J]. Research Policy, 2012, 41(9):1544-1554..

[2] Anne B., John P. U., Henning M. and Helle N.. The Effect of Financial Factors on the Performance of New Venture Companies in High Tech and Knowledge-Intensive Industries: An Empirical Study in Denmark. [J], International Journal of Management,2003,(12): 535 547.

[3] Gary D. Resources of the firm, Russian high-technology startups, and firm growth [J].Journal of Business Venturing, 2002, (17):533-576.

[4] Ling-Feng H. and Yao-Tsung T., Technology Investment Mode of Innovative Technological Corporations: M \& A Strategies Intended to Facilitate Innovation[J], The Journal of American Academy of Business, Cambridge, March 2005: 185 186.

[5] M. Kamil K., Dolun Ö., and Onur Ö.. Growth Plans of Small Businesses in Turkey: Individual and Environmental Influences [J].Journal of Small Business Management, 2006, 44(1):114-129.

[6] Michael L.H., Shanan G. Gibson. Determining the Common Problems of Early Growth Small Businesses in Eastern North Carolina [J] SAM Advanced Management Journal, Spring 2006:39-45.

[7] Penrose E., Theory of the Growth of the Firm [M], Oxford: Oxford University Press, 1995.

[8] Robert E. Carpenter and Bruce C. Petersen. Is the Growth of Small Firms Constrained by Internal Finance?[J].The Review of Economics and Statistics, May 2002, 84(2): 298-309

[9] Thorsten B, Asli D and Vojislav M. Financial and Legal Constraints to Growth: Does Firm Size Matter? [J] The Journal Of Finance Vol Lx, NO. 1 February 2005, 137 171.

[10] Rhee, J., Park, T., Lee, D. H. Drivers of Innovativeness and Performance for Innovative SMEs in South Korea: Mediation of Learning Orientation [J]. Technovation, 2010, 30 (1): 65-75. 